\title{
Solutions of Solid Timber and Glulam Bridge Example with Different Approaches in Turkey
}

\author{
Gökhan Şakar ${ }^{1+} \mathbb{D}$, Hüseyin Kürşat Çelik² ${ }^{2}$ \\ 1*Dokuz Eylul University, Department of Civil Engineering, Izmir, Turkey, (gokhan.sakar@ deu.edu.tr) \\ ${ }^{2}$ Dokuz Eylul University, The Graduate School of Natural and Applied Science, Izmir, Turkey, (hkursadcelik@gmail.com)
}

\section{ARTICLE INFO}

Received: April., 01. 2020

Revised: Dec., 05. 2020

Accepted: April, 13. 2021

Keywords:

Solid timber

Glulam

Timber bridge

EN5

NDS

Corresponding author: Gökhan Şakar

ISSN: 2536-5010| e-ISSN: 2536-5134

\section{ABSTRACT}

In this paper, the properties of solid timber and glulam materials are investigated. An existing steel bridge in Turkey is resized and reanalyzed with the SAP2000 analysis programme using solid timber and glulam. In this way, the potential of timber as an alternative to steel is examined. Solid timber and glulam solutions are realized with EN5 norms used in Europe and NDS norms used in America. Structural analysis results and quantities take-off are compared. As a result of the analysis, it was seen that internal forces and quantities take-off in EN5 solutions were higher than NDS. It is expressed that the reason for this is the resistance factors in EN5 are different and the solution parameters are more general expressions.

DOI: https://doi.org/10.36222/ejt.712893

\section{INTRODUCTION}

Various building materials have been used throughout the history in order to form a structural system, and steel and reinforced concrete materials are still widely used today. Research of alternative structural materials has increased for the get solution of topics like limited resource, sustainable structure, energy efficiency and environmental pollution. Therefore, potential of timber, the oldest construction materials of mankind, takes attention day by day, especially with the developing industrial facilities and technologies.

Since the millennium, the variety and frequency of research on wood has increased. General topics of studies about solid timber and glued laminated timber can be summarized like potential of timber according to physical and mechanical properties, positive and negative effects on environmental, energy efficiency etc.

Örs and Togay [1], investigated to production, cost and employment condition of timber industries in Turkey. They explained that the unit cost of timber buildings is not expensive comparisons between alternative materials and will be cheaper in future with the developments of production techniques. Doğangün et al [2] examined the earthquake performance of traditional wooden structures. They stated that the performance of timber structures was good in the past earthquakes in Turkey and they underlined that these structures should be encouraged. There is a similarity on results of studies about timber structures seismic performance around the world. Investigation of casualties in huge earthquake general in the world showed that platform framed timber structures had a little part in entire losses [3]. In addition, studies show that wood will make a major contribution to the reduction of $\mathrm{CO} 2$ emissions in the world and thus have a positive impact on the environment [4]. Moreover, using of timber could be preferred than concrete for large-scale highway bridges because of $\mathrm{CO}_{2}$ emissions and environmental friendly, resulting from life cycle assessments [5].

It is the fact that if there is a requirement to resisting the bigger loads and the long spans, solution can be more resistant materials. That is why the developments of glued laminated timbers (glulam). Glulam is produced by lamination of a few timber layers. Production phase can be summarized like; timbers taking from logs, drying, and lamination with hydraulic press [6]. In Fig. 1, producing of glulam beams can be seen.

There isn't significantly difference between solid timber and glulam. But, through the production techniques of glulam has important advantages against to solid timber. For example, different tree species can be used together in lamination process. Thus, with variety of layer dimension and layer numbers, glued laminated timber can be solution for 
engineering or architectural requirements. Possibility of using timber purify from defects while taking timber from logs ensure glulam more qualify than solid timber. Also, it can be obtaining same dimension of solid timber with using of small timber pieces. So, amounts of wastage materials can be reduced. Glued laminated timber had used first time in 1893 for auditorium construction in Basel, and today, bridges, houses, mosques, cinemas, theatres are being built with this material. Moreover, wide range of structures has been constructed with glulam beams [7].

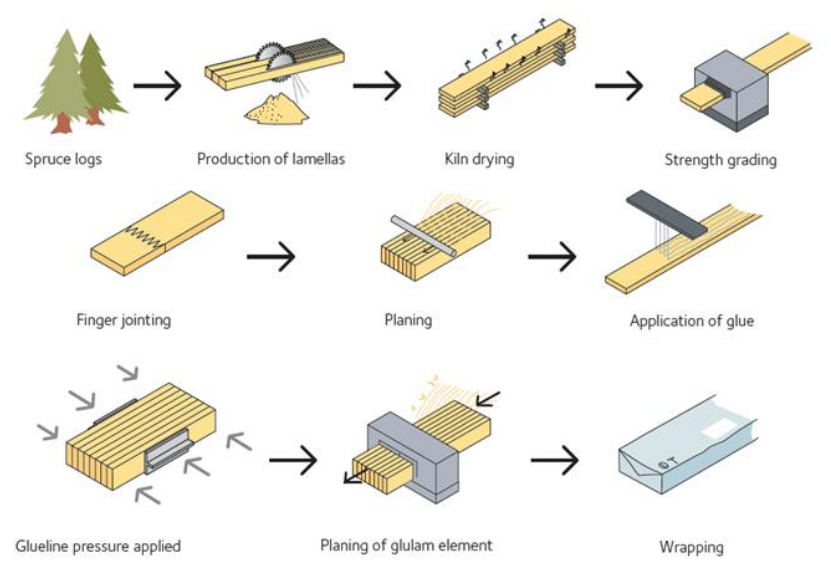

Figure 1. Producing Scheme of Glulam Beams [6]

Glulam is often used construction of pedestrian bridges and vehicle bridges. Crocetti enounce that timber becomes alternative choice for bridge construction in European countries because of developments of engineering wood products like glued laminated timber [8]. Fragiacomo et al focused on timber-concrete composite bridges. They explained that timber-concrete composite bridges have the same compression and tension strengths compared with concrete bridges. In addition, composite bridges are lighter and more environmental than concrete one [9]. Additionally, studies about cost comparison between timber, steel and prestressed concrete bridges showed the timber bridges initial costs cheaper than other alternatives, due to timber weight to strength ratio [10]. Similarly, glulam girder bridge cost cheaper than prestressed concrete bridge, including of fullscale fatigue and strength tests [11].

\section{PROPORTIES OF TIMBER}

Physical and mechanical properties have significant effects on structural durability, safety and costs. Strength properties of structural timber elements must be adjusted according to climate condition, role in structural system and etc. Therefore, in this part of paper, physical and mechanical properties of timber will be mentioned.

In generally, timber is fibrous, heterogenic and anisotropic structural materials taken from trees. Timber occurs with longitudinal living cells. Widths of this structure like tubules are bigger than a few hundred times of its heights. These tubules made the basis of structural system of timber and it has lignocelluloses chemical form. Jelly formed pectoselulose is resin that keep it together this tubules [12].

\subsection{Weight per volume}

Weight per volume of timber is ratio of sample weight to the volume at a given humidity. This value can change 0,1 $\mathrm{t} / \mathrm{m}^{3}$ to $1,5 \mathrm{t} / \mathrm{m}^{3}$ according to timber varieties [13].

With the relatively low weight to strength, timber has some advantages comparison between steel and reinforced concrete. Total consumed energy amounts including production of timber, construction of timber structures and service life will be low levels against to reinforced concrete and steel structures [4]. Also, thanks to its low weight to resistant, seismic performance of platform frame timber structures can provide to keep casualties low. For example, life loss in earthquakes can show in Tab. 1 [4].

Table 1

CASUALTIES IN EARTHQUAKES [4]

\begin{tabular}{|c|c|c|c|c|}
\hline \multirow[t]{2}{*}{ Earthquakes } & \multirow[t]{2}{*}{$\begin{array}{c}\text { Richter } \\
\text { Magnitude }\end{array}$} & \multicolumn{2}{|c|}{$\begin{array}{c}\text { Number of } \\
\text { Person Killed }\end{array}$} & \multirow[t]{2}{*}{$\begin{array}{c}\text { Number of } \\
\text { Platform Frame } \\
\text { Wood House } \\
\text { Strongly } \\
\text { Shaken(Estimated) } \\
\end{array}$} \\
\hline & & Total & $\begin{array}{l}\text { Wood } \\
\text { House }\end{array}$ & \\
\hline $\begin{array}{l}\text { Alaska, } \\
1964\end{array}$ & 8.4 & 13 & $<$ & \\
\hline $\begin{array}{l}\text { San } \\
\text { Fernando }\end{array}$ & 6.7 & 63 & 4 & 100000 \\
\hline $\begin{array}{l}\text { CA, } 1971 \\
\text { Edgecumbe, } \\
\text { NZ } 1987\end{array}$ & 6.3 & 0 & 0 & 7000 \\
\hline $\begin{array}{l}\text { Saguenay } \\
Q C, 1988\end{array}$ & 5.7 & 0 & 0 & 10000 \\
\hline $\begin{array}{l}\text { Loma Pieta } \\
\text { CA, } 1989\end{array}$ & 7.1 & 66 & 0 & 50000 \\
\hline $\begin{array}{l}\text { Northridge } \\
\text { CA, } 1994\end{array}$ & 6.7 & 60 & 2 & 200000 \\
\hline $\begin{array}{l}\text { Kobe } \\
\text { Japan, } \\
1995\end{array}$ & 6.8 & 63 & 0 & 8000 \\
\hline
\end{tabular}

\subsection{Thermal expansion and conductivity}

Thermal expansion coefficient of timber can be assumed 1,7 to $2,5^{*} 10^{-6} /{ }^{\circ} \mathrm{F}^{-1}$ at parallel to grain and coefficient for across the grain are generally five or ten times greater than parallel to grain coefficient. Timber is not good at thermal conductivity because of its nature that cellular and made by cellulose [13]. Timber is flammable, even exposed low fire temperature; it loses too much capacity of resistant parameters comparisons between reinforced concrete and steel [14]. But still it has got an advantage. Timber layers that exposing to fire will be charred and it covers the timber inner section from fire penetration. Also, timber has lower thermal expansion coefficient than steel and reinforced concrete $[13,14]$.

\subsection{Moisture}

Timbers mechanical properties is effecting too much with moisture ratio. As the moisture content of timber increases, pressure, tensile and bending strengths decrease. But this decreasing is stopped at the certain level of moisture saturation point [15]. 


\subsection{Mechanical properties}

It is not easy to investigate timber's mechanical properties because of its heterogenic and anisotropic nature. Timbers resistance against mechanical effects may be changeable by different species and same species's different samples. Timber's mechanical properties change with its anatomy, density, moisture content, applied force direction [16]. In Tab. 2 , can be seen some resistance values of timber.

Table 2

THE VALUES OF STRETCHING ACCORDING TO ITS CLASS OF GENUS AND SPECIES OF TIMBER MATERIALS [17]

\begin{tabular}{llllll}
\hline \hline \multirow{2}{*}{ Strength } & $\begin{array}{c}\text { Allowable Stress Values According To } \\
\text { Material Type And Class }\end{array}$ \\
\hline \hline \multicolumn{5}{c}{ Classes of Needle Leaf } & $\begin{array}{c}\text { Oak } \\
\text { and } \\
\text { Beech }\end{array}$ \\
\hline \multicolumn{4}{c}{ Trees } & 110 \\
1 & Bending & 1 & 2 & 3 & 100 \\
2 & Tensile & 130 & 100 & 70 & 100 \\
3 & Compression* & 105 & 85 & 0 & 30 \\
4 & Compression** & 20 & 85 & 60 & $40^{1}$ \\
5 & Compression* & $25^{1}$ & 20 & 20 & 10 \\
6 & Compression** & 9 & 9 & $95^{1}$ & 9 \\
\hline
\end{tabular}

It can be usable only if consider to gently crushing of materials, *: Parallel To Grain; **: Perpendicular To Grain, values given in $\mathrm{kg} / \mathrm{cm}^{2}$

Timber modulus of elasticity change with fiber direction. For example, elasticity modulus of pine is $10000 \mathrm{MPa}$ at parallel to grain, $3000 \mathrm{MPa}$ perpendicular to grain [17].

Because of timber's anisotropic material, design methods little more complicated than steel and reinforced concrete design methods. Also, the fact that the strength parameters perpendicular to the fibers are lower than the strength parameters parallel to the fibers is disadvantages of timber.

\subsection{Load duration}

Flexural strength of timber is inversely related with load duration. Deformation of timbers has direct proportion with load duration [16].

\section{TIMBER AND GLUED LAMINATED TIMBER DESIGN PRINCIPLES}

Today, various materials based on wood can be used in structure. Solid timber, glued laminated timber, plywood, OSB and other wood-based panels are entered in scope of Turkey Seismic Code-2018 [18]. Many countries, published codes or standards for structural timber design. According to Turkey Seismic Code-2018 timber structures design with 'Eurocode 5-Design of Timber Structures [19]. But, TS647Building code for Timber Structures still exists. So, this paper aimed on TS647-Building Code for Timber Structures [17], Eurocode 5-Design of Timber Structures [19], National Design Specification for Wood Construction [20]. These codes based on same principles and may show some differences about application of strength adjustments, load and resistance factors and load values [21]. So, these codes and standards are investigated and shortly explained of their design philosophies.

\subsection{TS 647-Building Code for Timber Structures}

In this code, timber is identified as solid timber and plywood that is used in construction of timber structures. The code includes different types of timber building construction and allowable stress design. According to TS647, mechanical properties of timber must be correlated with some factors given by different environmental conditions.

\subsection{Eurocode 5-Design of Timber Structures}

The code includes solid timber, solid timber, glued laminated timber and other wood based structural products and wood based panels. It takes into account of some requirements such as mechanical resistance, serviceability, durability and fire resistance.

This code depends on limit state design requirements. While designing with different limit states, materials mechanical properties, time dependent behaviour, climate conditions and situations like stages of construction must be notice.

According to EN5, materials characteristic properties must be adjust appropriate to various environmental conditions. These conditions is load duration, moisture content and changes of moisture. Load duration class is given with a table and samples. Service classes are characterized by moisture content in the materials corresponding to temperature of $20^{\circ} \mathrm{C}$ and the relative humidity of the surrounding air. Adjustment of characteristic values is made by given modification coefficient $\left(\mathrm{k}_{\bmod }\right)$ and deformation coefficient $\left(\mathrm{k}_{\mathrm{def}}\right)$. Resistance factors are listed as a table for different wood materials. For instance, factor of solid timber and glued laminated timber is 1,30 and 1,25 respectively. Design values of mechanical properties are calculated characteristic values divided by partial factors and multiplied with kmod. Stiffness properties such as modulus of elasticity and shear modulus are modified for serviceable limits states or ultimate limit states. Stiffness properties adjust with moisture conditions in serviceable limit states calculations. In ultimate limit states design, corrections are made considering load durations, service conditions and load factors [19].

\subsection{National Design Specifications for Wood Construction (NDS)}

Specification includes lumber, glued laminated timber, piles, poles, prefabricated wood I-joist, lumber composites, and wood based panels and cross laminated timber. It contents allowable stress design (ASD) methods and load and resistance factor design (LRFD) methods.

Similar to EN5, characteristic value of wood materials must be adjusted due to moisture, load duration and other requirements. Corrections are made by several coefficients. Some of this coefficient is only used in allowable stress design and some used in load and resistance factor design. So that, coefficients given in parentheses indicate which design method it belongs to. Also, adjustment of characteristic values is not applied for all resistance parameters. The application of coefficients is explained in the related sections of the specification and the table shows which coefficient will affect which parameters according to the type of material.

Some coefficients in the specification are common to all wood materials. These coefficients are load duration factor, temperature factor, resistance factor and time effect factor. Load duration factor (ASD) is used for loads with different periods than normal loading conditions (ten years period). Temperature factor values are given in tables considering moisture conditions and temperature values. It is used in cases where the limit value $37,78^{\circ} \mathrm{C}$ is exceeded. Resistance factors 
(LRFD) are given in table in accordance with timber materials types and resistance values. Time effect factor (LRFD) is given in tables according to load combination and for earthquake combinations, this value is taken 1 . Properties of solid timber material are corrected depending on load duration, moisture and temperature conditions, dimension, direction of load and grain, defects of timber, usage of combined elements, bearing area and time effects. Some coefficients decrease characteristic values while others increase. Also, some strength effects like stability of columnbeam and buckling are taking into account with adjustment coefficient. Similar to solid timber, properties of glued laminated timber are adjusted conditional on load duration, moisture, temperature, dimension, load direction, curvature, layer numbers, bearing area and time effects. Besides, several effects like stability of column-beam and buckling are considering to adjustment coefficient like solid timber. Resistance factor changes with different strength parameters [20].

\section{NUMERICAL ANALYSIS}

In order to examine the potential of timber as an alternative, analysis and design of an existing steel bridge was reanalyzed and redesigned using with timber and glued laminated timber. The existing steel bridge is a pedestrian bridge and was completed in 2015 . The steel pedestrian bridge was reanalyzed with TSC-18 [18] and TSDC-17 [21] which are existing codes in Turkey. Although NDS includes LRFD and ASD methods, EN5 includes only LRFD methods. So, LRFD design methods were applied in calculation of bridge design for timber bridge and glulam bridge. Also, as a result of the calculation, the sections found by LRFD method were smaller than those found by ASD method [23].

Steel bridge structural system can be showed in Fig. 2. The bridge consists of S275JR build up main beams and IPE180 profile joists. Build up main beams has made by steel plate, which is welded body and flanges of the profile. Metal decks are placed on the beams and bridge platform is obtained from reinforced concrete slab. Total span of the bridge is $44 \mathrm{~m}$, width is $11 \mathrm{~m}$. The height of the bridge rises $2.35 \mathrm{~m}$ inwards $19 \mathrm{~m}$ from the start and end points. Bridge geometry, restrain and build up section properties are given in Fig. 3 .

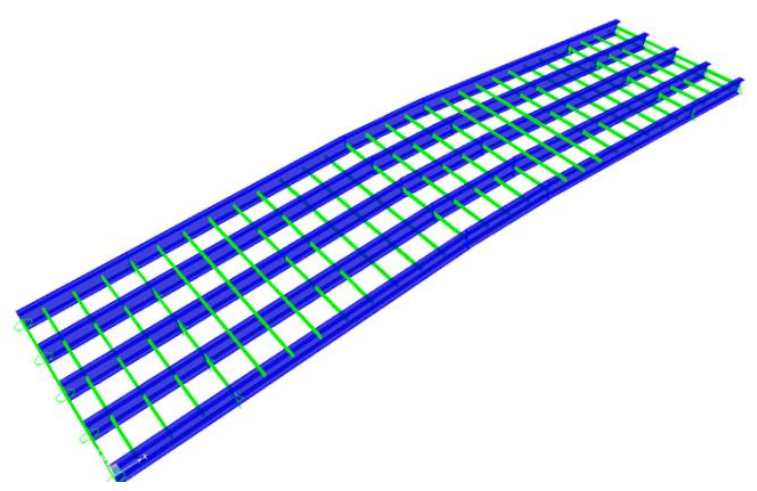

Figure 2. Steel structural system design model (blue for main beam, green for joists)

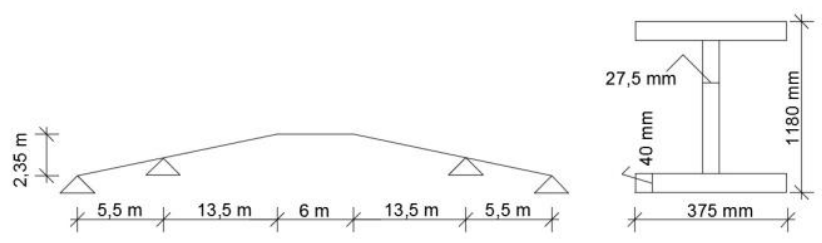

Figure 2. Bridge geometry and built up section dimensions

Structural system of the timber bridge is given in Fig. 4 and it contains main truss beams, joists solid beams and braces located on secondary direction. Cross section dimensions of timber structural system are given in Tab. 3. Easily available cross-sectional dimensions were selected and used. Timber bridges are designed with EN5 and NDS separately. In design, $\mathrm{C} 24 \mathrm{~h}$ and $\mathrm{C} 50 \mathrm{~h}$ solid timber and GL24h glued laminated timber beam was used. Load and resistance factors were taken from ASCE 7-16 for NDS, also taken from EN0 for EN5. Common loads used in bridge designs are given in Tab. 4.

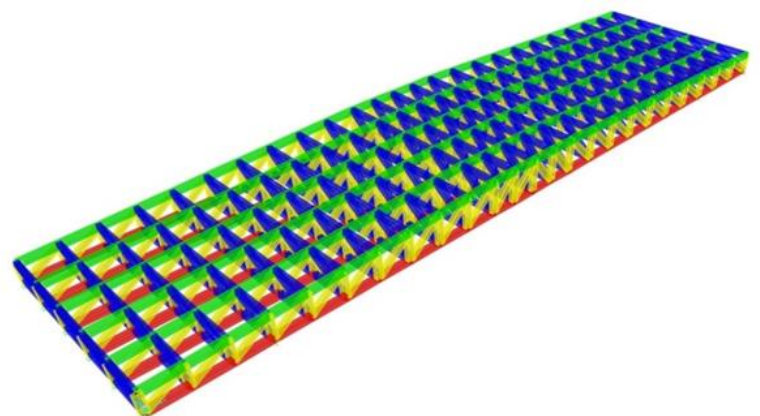

Figure 2. Timber load bearing system design model (the model used in all timber bridge design. Red and green represents the chords, yellow represents webs, blue represents the lateral stability element obtained the joists and bracing member.)

Table 3

DIMENSION OF TIMBER STRUCTURAL SYSTEM ELEMENTS SECTİON

\begin{tabular}{|c|c|c|}
\hline Element & $\begin{array}{l}\text { NDS } \\
(\mathrm{cm})\end{array}$ & $\begin{array}{l}\text { Eurocode } 5 \\
\quad(\mathrm{~cm})\end{array}$ \\
\hline $\begin{array}{c}\text { C24h Timber Truss } \\
\text { Chords }\end{array}$ & 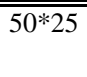 & $60 * 30$ \\
\hline $\begin{array}{l}\text { C24h Timber Posts } \\
\text { and Diagonals }\end{array}$ & $40 * 20$ & $50 * 25$ \\
\hline $\begin{array}{c}\text { C24h Timber } \\
\text { Lateral Stability } \\
\text { Elements }\end{array}$ & $40 * 25$ & $40 * 25$ \\
\hline $\begin{array}{c}\text { C50h Timber Truss } \\
\text { Chords }\end{array}$ & $45 * 20$ & $50 * 20$ \\
\hline $\begin{array}{l}\text { C50h Timber Posts } \\
\text { and Diagonals }\end{array}$ & $30 * 15$ & $40 * 20$ \\
\hline $\begin{array}{l}\text { C50h Timber } \\
\text { Lateral Stability } \\
\text { Elements }\end{array}$ & $30 * 20$ & $30 * 15$ \\
\hline $\begin{array}{l}\text { GL24h Glued } \\
\text { Laminated Timber } \\
\text { Truss Chords }\end{array}$ & $50 * 20$ & $60 * 25$ \\
\hline $\begin{array}{l}\text { GL24h Glued } \\
\text { Laminated Post } \\
\text { and Diagonals }\end{array}$ & $40 * 20$ & $50 * 25$ \\
\hline $\begin{array}{l}\text { GL24h Glued } \\
\text { Laminated Timber } \\
\text { Lateral Stability } \\
\text { Elements }\end{array}$ & $40 * 25$ & $40 * 25$ \\
\hline
\end{tabular}


Table 4

SAME LOAD VALUES TAKING INTO ACCOUNT

Slabs load $=15 \mathrm{~cm}$ concrete $+\underset{\mathrm{kg} / \mathrm{m}^{2}}{\text { mosaic-adhesive }+ \text { metal deck }=515}$
Live load $=500 \mathrm{~kg} / \mathrm{m}^{2}$
Snow load $=75 \mathrm{~kg} / \mathrm{m}^{2}$
Railing load $=50 \mathrm{~kg} / \mathrm{m}$
Wind Load $=50 \mathrm{~kg} / \mathrm{m}^{2}$

Span/800 was chosen as displacement limit at steel and timber bridge design. All bridge calculations were performed with SAP2000 v20 structural analysis program [24]. Maximum displacement of steel bridge was calculated as 3,94 $\mathrm{cm}$. Maximum displacement values of solid timber and glued laminated timber bridges are given in Tab. 5 .

Table 5

TIMBER BRIDGES MAXIMUM DISPLACEMENTS FROM ANALYSIS RESULTS

\begin{tabular}{ccc}
\hline \hline $\begin{array}{c}\text { Bearing System } \\
\text { Types }\end{array}$ & NDS $(\mathrm{cm})$ & Eurocode 5(cm) \\
\hline C24h Solid Timber & 3,92 & 3,91 \\
C50h Solid Timber & 4,07 & 4,09 \\
GL24h Glulam & 4,04 & 4,06
\end{tabular}

Largest stress ratio (requirements/capacity) showed from results is given below in Tab. 6 and quantities of structural elements given below in Tab. 7 .

Table 6

CAPACITY RATIO OF LOAD BEARING ELEMENTS

\begin{tabular}{|c|c|c|}
\hline Bearing System & ELEMENT TYPES & STRESS RATIO \\
\hline S275 & Main beam & 0,47 \\
\hline $\mathrm{S} 275$ & Joists & 0,41 \\
\hline C24h NDS & Main beam & 0,77 \\
\hline C24h NDS & Joists & 0,94 \\
\hline C50h NDS & Main beam & 0,78 \\
\hline C50h NDS & Joists & 0,86 \\
\hline GL24h NDS & Main beam & 0,78 \\
\hline GL24h NDS & Joists & 0,91 \\
\hline C24h EN5 & Main beam & 0,67 \\
\hline C24h EN5 & Joists & 0,95 \\
\hline C50h EN5 & Main beam & 0,53 \\
\hline C50h EN5 & Joists & 0,85 \\
\hline GL24h EN5 & Main beam & 0,66 \\
\hline GL24h EN5 & Joists & 0,95 \\
\hline \multicolumn{3}{|c|}{$\begin{array}{c}\text { Table } 7 \\
\text { QUANTITIES TAKING FROM SAP2000 }\end{array}$} \\
\hline $\begin{array}{c}\text { Bearing System } \\
\text { Types }\end{array}$ & \multicolumn{2}{|c|}{ Quantities } \\
\hline S275 & \multicolumn{2}{|c|}{110,074 ton } \\
\hline C24h NDS & \multicolumn{2}{|c|}{$211,742 \mathrm{~m}^{3}$} \\
\hline C50h NDS & \multicolumn{2}{|c|}{$132,94 \mathrm{~m}^{3}$} \\
\hline GL24h NDS & \multicolumn{2}{|c|}{$180,22 \mathrm{~m}^{3}$} \\
\hline C24h EN5 & \multicolumn{2}{|c|}{$271,255 \mathrm{~m}^{3}$} \\
\hline C50h EN5 & \multicolumn{2}{|c|}{$134,44 \mathrm{~m}^{3}$} \\
\hline GL24h EN5 & \multicolumn{2}{|c|}{$255,41 \mathrm{~m}^{3}$} \\
\hline
\end{tabular}

\section{Results}

Timber based materials have been found to be used in structural system for satisfying to lots of engineering or architectural requirements because of their positive characteristic properties. The most important reasons for this are its high strength to weight ratio and being a sustainable material.

There are codes and standards of various countries in the design of timber structures. In this paper, commonly used codes namely NDS and EN5 were used in analyzes. According to these codes, characteristic values of timber material must be adjusted depending on different reasons for structural design. This regulation is based on similar philosophy and may comprise some differences.

In this paper, the existing steel pedestrian bridge redesigned and reanalyzed with solid timber and glued laminated timber materials. The steel bridge was controlled with TSC-18 and TSDC-17. Vertical displacements were effective in the design of the steel bridge. While vertical displacement was dominant in main beams stress was dominant in lateral stability elements in solid timber and glued laminated timber design. Quantities, capacity ratios and vertical displacement results are given in the tables in related topics. According to the stress ratios given in Tab. 6, it is seen that the capacities of solid timber and glued laminated timber materials can be used more efficiently than steel. Since the vertical displacement criterion is dominant in stress in steel bridge solution, the use of material capacity remains low. In addition, since the weight of the bridge made of wood materials is less than that of the steel bridge, less earthquake force comes into the system and loads and stresses remain at lower levels. Therefore, timber structural system has more capacity ratio than steel structural system.

As a result of the analyses made with GL24h glued laminated timber and C24h solid timber, the structural system could be solved with approximately similar sections. On the other hand, it is difficult to obtain the required sections with solid timber and the material loss is considerable. In the use of glued laminated timber, the necessary elements can be preferred because they are easily produced and protection procedures are not required [25].

The materials GL24h and C24h were chosen because they are readily available from the manufacturers. However, as can be seen from the values given in Tab. 7, the use of more strength timber material had a positive effect on the results. But, since the $\mathrm{C} 50 \mathrm{~h}$ solid timber is special production and difficult to supply, the unit cost is high. Thus, it has expensive cost than GL24h and C24h materials. This paper not includes the cost analysis because of the cost is variable depends on many factor. As the costs are variable and depend on many factors, cost analysis is not performed in the study.

Analysis results from NDS and EN5 have some differences. The main reason for this is diversity of resistance factors. The strength coefficients of NDS in timber material corrections are taken different for tenacity parameter. In contrast, all parameters in EN5 are reduced by the same parameter. This result in higher quantities in the solutions made with EN5 than in NDS. This result is similar with literature knowledge [22]. 


\section{REFERENCES}

[1] Y. Örs and A. Togay, "Production, price and employment in Turkish wood construction industries", Journal of Polytechnic, vol. 7, no. 1, pp. 53-61, 2004.

[2] A. Doğangün, R. Livaoğlu, Ö. İ. Tuluk and R. Acar, "Earthquake performances of traditional timber structures", presented at Deprem Sempozyumu, Kocaeli, Turkey, pp. 797-799, 23-25 March 2005.

[3] J. H. Rainer and E. Karacabeyli, "Ensuring good seismic performance with platform-frame wood housing", National Research Council of Canada, Institute for Reseacrh in Canada, Construction Technology Update No.45, 2000. https://doi.org/10.4224/20327963

[4] A. H. Buchanan, "Can timber buildings help reduce global $\mathrm{CO}_{2}$ emission", presented at $9^{\text {th }}$ World Conference on Timber Engineering, Portland, USA, 1, pp. 2204-221, 2006.

[5] R. O'Born, "Life cycle assessment of large scale timber bridges: a case study from the World's largest timber bridge design in Norway", Transportation Research Part D: Transport and Environment, vol. 59, pp. 301-312, March, 2018. https://doi.org/10.10 16/j.trd.2018.01.018

[6] E. Borgstörm, "Design of Timber Structures", $2^{\text {nd }}$ ed., vol. 1, Stockholm, Sweden, Swedish Forest Industries Federation, 2016.

[7] R. C. Moody and R. Hernandez, "Glued-Laminated Timber", in Engineering wood products-a guide for specifiers, designers and users, S. Smulski, Ed., Madison, Wisconsin, USA, PFS Research Foundation, 1997, pp. 1-1-1-39.

[8] R. Crocetti, "Timber bridges: general issues, with particular emphasis on Swedish typologies", presented at 20. Internationales Holzbau-Forum IHF, Garmish, Germany, 3-5 December 2014.

[9] M. Fragiacomo et al, "Timber-concrete composite bridges: three case studies, Journal of Traffic and Transportation Engineering, vol. 5., no. 6, pp. 429438, 2018. https://doi.org/10.1016/j.jtte.2018.09.001

[10]R. A. Behr et al, "Cost comparison of timber, steel and prestressed concrete bridges, Journal of Structural Engineering, vol. 116, no. 12, pp. 34483457, 1990.

[11] M. Tazarv et al, "Glulam timber bridges for local roads", Engineering Structures, vol. 118, pp. 11-23, 2019.

https://doi.org/10.1016/j.engstruct.2019.03.012

[12] J. T. Ricketts and S. F. Merrit, "Building design and construction handbook", $6^{\text {th }}$ ed., New York, USA, McGraw-Hill Companies, 2001.

[13]R. J. Ross, "Wood handbook: wood as an engineering material", Wisconsin, USA, United States Department of Agriculture Forest Service, 2010 .
[14] M. H. Ramage et al, "The wood from the trees: the use of timber in construction", Renewable and Sustainable Energy Reviews, vol. 68, pp. 333-359, February,2017. https://doi.org/10.1016/j.rser.2016.09.107

[15]S. K. Duggal, "Building materials", $3^{\text {rd }}$ ed., Daryaganj, New Delhi, New Age International, 2008.

[16] J. M. Dinwoodie, "Timber: its nature and behaviour, $2^{\text {nd }}$ ed., London, United Kingdom, Taylor\&Francis, 2004.

[17]TS 647-Building Codes for Timber Structures, Ankara, Turkey, Turkish Standards Institution, november, 1979.

[18] TSC-18-Turkish Seismic Design Code, Ankara, Turkey, Ministry of Environment and Urbanization, 2018.

[19] Eurocode 5-Design of Timber Structures, European Committee for Standardization, 2004.

[20]NDS, National Design Specifications for Wood Construction, USA, American National Standards Institute, 2018.

[21]TSDC-17, Turkish Steel Design Code, Ankara, Turkey, Ministry of Environment and Urbanization, 2017.

[22]J. P. Wacker and J. S. Groenier, "Comparative analysis of design codes for timber bridges in Canada, the United States, and Europe", Transportation research record, no. 2200, pp. 163168, 2010. https://doi.org/10.3141/2202-19.

[23] J. Showalter, H. B. Manbeck and D. Pollock, "LRFD versus ASD for wood design", presented at ASAE Annual International Meeting,Orlando, Florida, USA, July 12-16, 1998.

[24] SAP2000, Structural Analysis Program-Integrated Finite Element Analysis and Design of Structures, Analysis Reference, Berkeley, California, USA, 2019.

[25] A. Çekiç et al, "Properties of timber and glulam beams, usage and design of structures and strengthening of glulam beams with FRP", BSc graduation thesis, Department of Civil Engineering, Dokuz Eylul University, Izmir, Turkey, 2019.

\section{BIOGRAPHIES}

Gökhan Şakar is an associate professor in the Department of Civil Engineering at the Dokuz Eylul University where he has been a faculty member since 1997. He also completed his $\mathrm{PhD}$ at Dokuz Eylul University. His main research interest is strengthening of reinforced concrete structures especially with fiber-reinforced polymer materials. He has been involved in experimental research on the behavior of reinforced concrete structures. $\mathrm{He}$ has many papers on this subject. He is also interested in steel and timber structures. He currently has several master and $\mathrm{PhD}$ students and continues to experiment in the field of structural mechanics.

Hüseyin Kürşat Çelik received his BSc degree in civil engineering from Dokuz Eylul University (DEU) in 2019. Currently, he is an MSc student in Structural Engineering at The Graduate School of Natural and Applied Science, Dokuz Eylul University. His main research interest is timber structures. 